\title{
Examining sustainability performance in the supply chain: The case of the Greek dairy sector
}

Michael Bourlakis ${ }^{\mathrm{a}}$, George Maglaras $^{\mathrm{b}}$, David Gallear $^{\mathrm{c}}$, Christos Fotopoulos $^{\mathrm{d}}$

${ }^{a}$ Professor Michael Bourlakis (Corresponding Author) Cranfield School of Management, Cranfield, Bedford MK43 0AL, UK, Telephone: +44 (0)1234 751122;

e-mail: m.bourlakis@cranfield.ac.uk

${ }^{\mathrm{b}}$ Dr George Maglaras, Institute for Retail Studies, University of Stirling, FK9 4LA Stirling, Scotland, UK, Telephone: +44 (0) 1786466454; email: george.maglaras@stir.ac.uk

${ }^{\mathbf{c}}$ Dr David Gallear, Brunel Business School, Brunel University, Kingston Lane, UB8 3PH, Uxbridge, UK, Telephone: +44 (0)1895 267077, e-mail: David.Gallear@brunel.ac.uk

${ }^{\mathrm{d}}$ Professor Christos Fotopoulos, Department of Business Administration in Food and Agricultural Enterprises, University of Western Greece, 2 G. Seferi Str., Agrinio, 30100, Greece, Telephone: +30 (0) 6976760281; email: chfotopu@cc.uoi.gr 


\section{Bio Page}

Professor Michael Bourlakis holds the Chair in Logistics \& Supply Chain Management at Cranfield School of Management where he is also the Head of the Supply Chain Research Centre. His research interests are in the fields of retail logistics, food supply chain management and the interaction between e-business operations and supply chain management. He has published in many leading journals and has received funding from various national and international bodies.

Dr George Maglaras is an Early Career Fellow at the Institute for Retail Studies, University of Stirling, Scotland, UK. His current research is mainly focused on the field of food supply chains and he has published in the International Journal of Logistics Management and the Food Quality and Preference Journal.

Dr David Gallear is Reader in Operations Management and Enterprise at Brunel Business School. His research interests are in the fields of operations strategy, quality management and supply chain management, with particular interest focused on examining the nature, form and determinants of supply chain purchasing strategy relationships, and on sustainability and corporate responsibility in supply chains. He has published in numerous international journals including International Journal of Production Economics, OMEGA and Technovation.

Professor Christos Fotopoulos is an Emeritus Professor at the University of Western Greece. His current research is focused on the fields of food supply chains and total quality management in food companies. He has published in various journals including the European Journal of Marketing, the International Journal of Logistics Management and the Journal of Total Quality Management and Business Excellence. 


\section{Research Highlights}

- We test an interdisciplinary sustainability framework where marketing and operations, sustainability-related indicators are integrated.

- The large dairy manufacturers are the "sustainability performance champions" in the examined chain followed by catering firms and wholesalers.

- Breeders underperform in key indicators including flexibility in delivery to extra point of sales and total evaluation of firm's performance.

- A concerning finding relates to poor product conservation time where urgent action is needed by all supply chain members. 


\begin{abstract}
Key words
Abstract

This paper evaluates the sustainability performance of the Greek dairy chain and the performance of its individual members by using key indicators in relation to efficiency, flexibility, responsiveness and product quality. We assessed the importance of these indicators based on the relevant perceptions of key members of this chain. A structured questionnaire was developed where nineteen sustainability-related issues were examined. Two hundred and fifty three members of the Greek dairy supply chain responded including breeders, manufacturers, wholesalers, retailers and catering companies. Our findings illustrate the immediate need for improvement in many key sustainability performance indicators. They also show the critical role of large dairy manufacturers who are the "sustainability performance champions" in this chain and are the driving force for the implementation of many sustainability initiatives.
\end{abstract}

Keywords: Sustainability, performance, sustainability performance indicators, food supply chain, Greek dairy sector. 


\section{Examining sustainability performance in the supply chain: The case of the Greek dairy sector}

\section{Introduction}

According to Karmarkar (1996), business and management researchers tend to only examine their principal domain / function, such as marketing, operations, or finance and tend to ignore research interdependencies and synergies between their domain / function and others. However, to examine contemporary business and management issues such as business sustainability performance, a cross domain approach is required where separate domains are cross-examined in an integrated and holistic fashion (Chabowski, et al. 2011).

In this work, we examine the integration between the marketing and operations domains. These domains are considered by Karmarkar (1996, p.125) to be a "natural pair" [of functions] due to the fact that operations deal with the production-supply frontier and marketing examines the consumer preference-demand frontier. Such recognition led Malhotra \& Sharma (2002) to present a "marketing operations integration framework" noting various integration opportunities between the marketing and operation domains. One of these opportunities relates to firm / organisational performance where they recommend further research in general and with a focus on supply chain issues in particular (Malhotra \& Sharma 2002).

Our paper addresses their recommendation by examining the Greek dairy supply chain (SC) which encompasses various industrial, business and end-to-end intermediaries such as breeders, manufacturers, wholesalers, retailers and catering firms. In general, supply chain 
management (SCM) is at the confluence of many disciplines and it is placed at the core interface between marketing, logistics and operations domains. This view is supported by most marketing, logistics, operations and SCM scholars (see Boyer \& Hult 2005; Ellinger 2000; Jüttner, et al. 2010; Lambert \& Cooper 2000; Mentzer, et al. 2001). To this end, SCM is defined as the "integration of key business processes from end user through original suppliers that provide products, services and information that add value for customers and other stakeholders" (Lambert \& Cooper 2000, p.66). In relation to the firm / organisational performance noted earlier, Mentzer, et al. (2001, p.18) stress that SCM involves "the systematic strategic coordination of the traditional business functions and the tactics across these business functions within a particular company and across businesses within the supply chain, for the purpose of improving long-term performance of the individual companies and the supply chain as a whole".

Based on the above, it is evident that there is a growing need for closer co-ordination between operations and marketing domains along the SC where improving individual firm and chain performance is extremely important. In addition, over the past few years, sustainability performance has emerged as an important factor that is increasingly influencing stakeholders' evaluations of how firms' address market demand through their operations processes (see for example, Keeble, et al. 2003). Despite growing recognition of the SC's role in sustainability performance, it has been noted (Pagell \& Wu 2009) that research on the development of sustainability in SCs (with some notable exceptions, e.g. Zhu, et al. 2008) has so far tended to focus on studies of a single domain (or activity or echelon) rather than looking at the entire chain (Rao \& Holt 2005). Furthermore, it has been argued that in practice a majority of companies have focused mainly on their own sustainability performance and that only a few 
feel responsible also for their fellow chain members' sustainability activities (Hall 2000; Gerbens-Leenes, et al. 2003).

Three key propositions emerge from the arguments put forward so far. One, that interdisciplinary research, bridging the marketing and operations domains, is crucial for advancing (and shaping) our understanding of contemporary business practice. Two, that increasingly integral to such advances are considerations relating to sustainability performance. Three, that SCM provides the conduit for examining the integration of marketing and operations domains by virtue of its advocation and emphasis on the need to extend integration between processes from a single company (inter-firm level) to various companies (intra-firm level) within the same SC to achieve a sustainable (long-term) competitive advantage (see Ellinger 2000).

Despite these observations, there has been a distinct lack of empirical analysis in the extant literature based on chain-wide sustainability performance measurement, particularly in food chains which are under increasing levels of scrutiny about their sustainability credentials. Our work aims to shed light on this shortcoming by examining firms collaborating with other firms of the same SC. In this paper, we cross-analyse the performance of various firms in the Greek dairy SC aiming to ascertain whether these firms directly or indirectly affect the performance of other SC members and illustrate the overall supply chain performance (SCP). More importantly, we aim to determine whether any of these firms can actually contribute to heightened, integrated (end-to-end chain), sustainable performance in this food chain. To achieve this, we use sustainable SCP measurement indicators as identified in the extant literature for relevant SC operations at firm level. 
Thus, the objective of this paper is to fill the aforementioned gap in the literature, by 'bringing together' and integrating in our empirical work the sustainability performance of various operational domains (functions) at firm / intermediary level aiming to illustrate their impact on the sustainability performance of the whole SC. This approach is supported by the literature which suggests that SCP measurement should include as many chain members as possible (Lai, et al. 2002) and should assess the performance of the SC as a whole as well as the performance of each organization separately (Van der Vorst 2006; Gunasekaran, et al. 2004). The literature also suggests that chain members should have a common set of performance indicators that will help them to compare their performance within the chain and to gauge the end performance of the chain (Aramyan, et al. 2007).

Finally, we investigate whether there are significant differences in the SC sustainability performance between various members of the Greek dairy chain and we examine whether they over-perform or under-perform. To conclude, the study aims to answer the following research questions:

Are there any major differences in the SC sustainability performance between the key members of the Greek dairy chain?

Against which sustainability performance indicators do these members over-perform or underperform and what is the impact of their performance on the rest of the chain?

How does the Greek dairy chain perform in terms of the major sustainability indicators?

The rest of the paper is set out as follows: the next section discusses the concepts of sustainability and performance measurement in food SCs and introduces the key performance indicators used in our empirical work. A subsequent section describes the Greek dairy sector 
on which our empirical work is focused and analyses the methodology employed. The key results are then presented, followed by a separate section discussing these results in detail before the paper concludes.

\section{Literature review}

Food SCs are experiencing increasing consumer demands on food quality and sustainability (Van der Vorst, et al. 2009). Many different stakeholders are becoming increasingly vocal in their demands for sustainable performance, and these demands determine how firms align their operations and marketing activities with the principles of sustainable development (Keeble, et al. 2003). Both consumers and buying firms are now much more interested in the origin of products, and governments and industry policy bodies are demanding sustainability performance reporting (Keeble, et al. 2003; Kolk 2004).

\subsection{Sustainability and food supply chains}

Food items tend to be produced in a complex system made up of many processes connected in SCs (Gerbens-Leenes, et al. 2003). The operations and marketing functions of the SC members play a critical role in developing management systems and implementing decisions that affect sustainability performance (Klassen 1993, in Angell \& Klassen 1999). Green marketing is greatly influenced by the sustainability credentials of most SC members' production capabilities (Sarkis 2001). Customer concerns about environmental and social responsibility must nowadays be properly integrated with other dimensions of value when managing stakeholders (Angell \& Klassen 1999). While process design and technology typically determine waste generated and resources and energy consumed, stakeholder 
relationships (e.g. supplier partnerships), logistics, and customer relationships magnify or attenuate sustainability performance and risks related to production (Angell \& Klassen 1999).

Carter \& Rogers (2008) contend that when environmental and social aspects of sustainability that can extend beyond a firm's boundary, are coupled with economic objectives into a deliberate long-term strategy, the inclusion of SC activities in a firm's sustainability can create a pervasive and less imitable set of processes; it can also create potential bases for competitive advantage for them and associated chain members (Carter \& Dresner 2001; Carter \& Rogers 2008). To this end, Carter \& Rogers (2008) defined sustainable SCM as:

“the strategic, transparent integration and achievement of an organisation's social, environmental, and economic goals in the systemic coordination of key interorganisational business processes for improving the long term economic performance of the individual company and its supply chains".

\subsection{Sustainability performance indicators for dairy food chains}

Angell \& Klassen (1999) propose that when measurement (and incentive) systems include sustainability considerations, sustainability performance improves, without sacrificing other aspects of operating performance. Whilst the literature has recently focused on analysing sustainability issues around the triple-bottom-line's economic, environmental and social axes, it is evident that differing sustainability issues are faced in different industries (Maloni \& Brown 2006) and by different companies in the same business sector (Gerbens-Leenes, et al. 2003) and thus by different SCs. Retailers in the food industry, for example, must be prepared to demonstrate responsible sustainable practices in addition to offering more environmentally friendly products (Maloni \& Brown 2006). 


\subsubsection{Indicators framework}

Any judgement or appraisal on sustainability performance would be difficult without context and comparison (Kolk 2004). As such, differences in sustainability performance outcomes need to be evaluated in order for SC actors to gauge their sustainability contribution and identify where improvement is needed. Such differences can be examined against key sustainability indicators. The indicators used in this study were derived from a careful and comprehensive review of the literature on sustainability in SCs with a particular focus on food chains. We were unable to identify any existing, single, comprehensive typology (or even a set) of sustainability indicators in the literature, so instead we undertook to identify and extract the relevant indicators ourselves.

We organised these indicators within a framework widely used in the SC literature (Aramyan, et al. 2006; Shepherd \& Gunter 2006). This has been proposed taking into account the exceptional circumstances of food chains, such as seasonality in production, product safety and sensory properties (Aramyan, et al. 2006). It comprises four categories into which the sustainability SCP indicators identified in this study can be arranged: efficiency, flexibility, responsiveness and product quality. As has been noted by Shepherd \& Gunter (2006), the inclusion of non-efficiency/cost measures is extremely important, particularly in the sustainability context, as relying on only efficiency/cost indicators can produce a misleading picture of SCP (Chen \& Paulraj 2004).

\subsubsection{Efficiency indicators}

According to Lai, et al. (2002), efficiency refers to the proper utilization of resources and can be measured with several types of costs and profits (e.g. operating costs). The use of 
production processes to enhance total social-economic welfare, and use of resources to cater for broad social needs as opposed to the narrow self-interests of the firm (Frederick 1960) has been a mainstay of sustainability thinking since it first emerged (Angell \& Klassen 1999). The operations of the food industry are known to be capable of having a significant impact on the environment. The production equipment, methods, practices and delivery systems can limit or reduce the negative impacts of products or services on the natural environment (Shrivastava 1995; Angell \& Klassen 1999). Deployment of environmental technologies in production and operations, for example, can drive down operating costs as well as reducing long-term risks (Angell \& Klassen 1999). At the front end of the dairy SC, farming techniques and associated costs (including labour costs) have been identified as an important sustainability factor in the literature (Maloni \& Brown 2006).

Storage costs in a food SC are another important indicator of chain members' sustainability performance. Storage costs are highly correlated with stock turns and in the context of the dairy chain they can have a high correlation with waste. Nevertheless, many actors in the dairy SC are dependent on at least short-term bulk cold storage (Coley, et al. 2009). Energy use in chilled storage therefore represents an important sustainability cost related to efficiency (Coley, et al. 2009).

A relevant crucial cost consideration in every food SC is delivery and distribution costs. 'Food miles' (the distance travelled from breeder to end- user) affects fuel consumption and the wider issue of global warming (Maloni \& Brown 2006). Delivery and distribution costs are also affected by the mode of transportation. Environmentally responsible logistics is a rapidly emerging aspect in delivery and distribution (Carter, et al. 2000; Maloni \& Brown 2006). Noting the often high distribution costs in dairy SCs, reducing distance travelled and 
using 'greener' logistical options (Ilbery \& Maye 2005) could result in significant efficiencies and cuts in carbon emissions, and, hence, positive economic and environmental outcomes, as has been widely recognised by the EU, governments and researchers alike (Gerbens-Leenes, et al. 2003).

Similarly, waste minimisation forms a distinct element of operations strategy (Angell \& Klassen 1999) in any sustainability focused management, and it has been proposed that environmental technologies that minimise waste can be adopted most quickly in industries, such as dairy, that have a 'process-based' operations architecture (Angell \& Klassen 1999). The literature presents waste as one of the most pervasive sustainability issues for food SCs (Maloni \& Brown 2006). Waste performance has been identified as a frequently used indicator for environmental sustainability in food production (Gerbens-Leenes, et al. 2003). Since waste consumes resources without providing increased value, sustainability policies within the SC can help reduce expenditures and costs, and improve efficiency and profits (Handfield, et al. 1997). Accordingly, waste reduction has the potential for significant efficiency gains (Sarkis 2001) and positive economic outcomes (e.g. for shareholders) and environmental and social outcomes (Handfield, et al. 1997).

As Carter \& Rogers (2008) argue, there are sustainable chain activities which contribute to potential economic advantages which are highly applicable in the dairy food chain context, such as lower health and safety, recruitment and labour turnover costs that result, for example, from safer warehousing/transportation and better working conditions (Brown 1996; Carter, et al. 2007). The latter can also increase motivation and productivity, and reduce absenteeism (Holmes, et al. 1996; McElroy, et al. 1993) hence improving overall labour cost expenditure (Carter \& Rogers 2008). It has also been noted that higher costs can be a barrier to implementing sustainable SCs, although joint efforts of chain members can help to control 
them (Seuring \& Müller 2008). Consequently, financial cost is an important sustainability performance indicator.

Furthermore, there is evidence in the literature that the management of environmental performance is linked not only to cost savings but also to market gains (Klassen \& McLaughlin 1996; Handfield, et al. 1997). In this vein, Kolk (2004) identified gross profit margin as a key sustainability performance indicator.

\subsubsection{Flexibility indicators}

Flexibility is a critical SCP element and measures the capability to provide individual services or products to customers (Gunasekaran, et al. 2004). Flexibility indicates a SC members' ability to cope with changes (often rapid) in demand or supply (Shepherd \& Gunter 2006). Dynamism and mobility, that is to say flexibility in delivering to extra points of sale, and in extra volume orders, has been noted as an important food chain sustainability factor, particularly for smaller actors (Ilbery \& Maye 2005). Process flexibility can directly support sustainability management activities (Angell \& Klassen 1999) as the ability to change the output levels of goods produced (Aramyan, et al. 2007) enables the chain members to maintain competitiveness and sustainable practices (Sarkis 2001) and helps them to minimise wastage. Flexibility, supported by efficient logistics practices, is essential in the dairy industry to help the SCs flow (Sarkis 2001). As with volume flexibility, the ability to change planned delivery points can help to reduce waste and fuel consumption.

\subsubsection{Responsiveness indicators}

Responsiveness (together with cost) has been observed to be a dominant SCP indicator (Persson \& Olhager 2002), highly relevant in the food SC sector as evidenced in the 
associated literature (Molnar \& Gellynk 2009; Trienekens, et al. 2008; Aramyan, et al. 2007). Measures of responsiveness reflect the ability of the food chain to deliver high customer service (Shepherd \& Gunter 2006). The perishable nature of the products along the dairy food chain makes responsiveness in meeting the arranged lead times, responsiveness in delivering to the arranged point of sales (location), and responsiveness in delivering the product as ordered (correct type and quantity) among key competitive and sustainability factors (Ziggers \& Trienekens 1999). Although primarily borne out of food health and safety concerns, Ilbery \& Maye (2005) note a greater propensity for the creation of 'local' and 'shorter' food SCs to enhance sustainability, which can be more responsive to lead time, delivery location and product volume/mix changes.

\subsubsection{Product quality indicators}

Product quality is also an important and widely used criterion for measuring SCP (Molnar \& Gellynk 2009; Trienekens, et al. 2008; Aramyan, et al. 2007) and it becomes more important in food SCs.

Quality of raw materials is an important 'shared responsibility' for SC members, particularly given its total lifecycle impact potential (Lewis 2005). Poor raw material quality can lead to alternative sourcing by downstream actors (Ilbery \& Maye 2005 p.338) and, hence, can seriously undermine business sustainability. An operational strategy focused on quality is more likely to allow the successful implementation of a more sustainable SC strategy (Angell \& Klassen 1999). Furthermore, quality is recognized as a key sustainability performance indicator (Keeble, et al. 2003) and as Ilbery \& Maye (2005) note, food chains are using quality as a means to address consumers' environmental anxiety. Product conservation time is a crucial aspect of quality in every food SC, however different tiers in the dairy chain deal 
with different product types - those upstream with products for immediate further processing and those downstream with ready for consumption (packaged) foods. Thus, different chain members will have different perspectives on product conservation time which is inextricably linked to the amount of waste that a SC produces (Heller \& Keoleian 2003).

Furthermore, in the food industry as a whole, food traceability has become a major issue, exacerbated by threats from terrorism and disease (Van der Vorst, et al. 2001; Maloni \& Brown 2006). Traceability information is crucial in the event of a food crisis in order to manage product recall actions (Dabbene \& Gay 2011), enabling chain members to more rapidly and cost effectively isolate problems, control disease and reduce impacts from tampering (Maloni \& Brown 2006). In this way, traceability is an important social sustainability issue since it aims to protect human health by maximising the safety of food products (Carter \& Rogers 2008). Furthermore, traceability allows chain members to acquire information regarding product flows. This is important from the social perspective as consumer/stakeholder attention shifts away from product price and appearance towards the origin (place and people) supplying the food products (Ilbery \& Maye 2005). Despite the profound benefits, the implementation of chain-wide traceability systems can be problematic since it is often implemented disjointedly between each chain member.

Another key issue is packaging where there is significant potential for producing products which are more environmentally-friendly and cost less (Handfield, et al. 1997). Good quality packaging with enhanced labelling could positively impact the economic performance of SC members (Tracey, et al. 2005) through cost savings due to reduced packaging waste (Carter \& Rogers 2008). Packaging of good quality is likely to become increasingly important as regulatory and/or consumer demands for returnable or recyclable packaging increase (Angell 
\& Klassen 1999). Product packaging also affects social sustainability too as enhanced labelling can help to promote healthier eating (Maloni \& Brown 2006). Packaging in food SCs is an increasingly scrutinised and important sustainability issue (Heller \& Keoleian 2003).

Finally, engaging in sustainable behaviour in the SC can make an organisation and the chain itself more attractive to a raft of stakeholders including suppliers, customers, employees and shareholders, therefore enhancing reputation (Carter \& Rogers 2008). Thus, we propose two overall evaluation indicators. The first to examine opinions about firm's overall sustainability performance directly and the second to examine the market's perceived opinion about the firm's sustainability performance.

Overall, although the current literature includes many research papers that deal with SCP measurement (see for example, Gunasekaran, et al. 2004), there seems to be a lack of empirical analysis based on sustainability performance indicators and their subsequent measurement in order to assess the actual sustainability performance of specific SCs (Aramyan, et al. 2007; Van der Vorst 2006) and more importantly, in food chains (Aramyan, et al. 2006) where sustainability is a key issue (Matopoulos \& Bourlakis 2010).

\section{Sector and methodology}

The data used in this study consist of questionnaire responses from managers in the Greek dairy SC. The Greek dairy sector has a key role in the Greek food industry. It is the third most important sector in Greek food and drink production representing over $17 \%$ of total production value and it contains some of the larger food manufacturers in the country. The Greek dairy chain is also characterized by a high level of competition between its members. 
Particularly, in the past few years, small countryside-based dairy manufacturers have gained market share from traditional large firms. The Greek dairy products are available to consumers primarily through large supermarkets but they are also available via other small retail (e.g. bakeries, groceries) and food service outlets (e.g. restaurants). These products are distributed by large manufacturers who command their own distribution channels.

Additionally, small and medium-sized manufacturers have limited production capabilities and produce dairy products in order to satisfy local needs. Some wholesalers with significant importing activity also supply the market with famous dairy brand names.

Our sample included six different types of members of the Greek dairy SC: breeders, small dairy manufacturers, large dairy manufacturers, wholesalers, retailers and catering firms. It is useful to clarify that we examined small and large dairy manufacturers separately as they returned significantly different performance.

In general, the most important Greek dairy products are milk and cheese in terms of production and sales value (ICAP 2011) and, in our sample, we included firms with their main business activities focused on these two products. These firms were traced following a systematic search of appropriate business directories (e.g. ICAP Business Directory). In addition, our sampling frame included firms representing every Greek region. The latter is important as most primary members / breeders of this SC are located in numerous geographical regions. We conducted a survey by using a structured questionnaire (see Appendix) with a number of sustainability performance measures. It is worth stressing that these sustainability performance measures were pre-tested via qualitative interviews with a sufficient sample of senior supply chain managers and senior academics (professors). These managers and academics provided valuable comments and feedback that was incorporated in 
our final list of sustainability performance measures (and the final, structured questionnaire). Hence, the final list of indicators was considered as appropriate for measuring sustainability performance in the Greek dairy food chain. It is also important to note that none of the above managers or academics was part of the final, quantitative survey of this work. Overall, surveys are successful research instruments and they have been widely used in past studies regarding SCP evaluation (Molnar \& Gellynk 2009; Chow, et al. 2008).

The final questionnaire consisted of two sections: in the first section, we included questions about the four categories of sustainability performance indicators (efficiency, flexibility, responsiveness and product quality) and two more questions about perceptions regarding the total evaluation of sustainability indicators. The measurement indicators for efficiency were assessed in relation to costs as a percentage of firm's turnover. Firms regularly calculate these ratios (indicators) and are willing to provide them, thus we took advantage of their availability to enhance data objectivity. The measurement indicators for flexibility, responsiveness, product quality and total sustainability evaluation were assessed on a seven-point scale $(1=$ Very satisfying performance to $7=$ Very unsatisfying performance) where the respondents indicated their perceptions for the issues under examination. Here, it should be highlighted that although any self-reported, perceptual measure (indicator) is subject to bias, similar methods have been used extensively by several other studies (Sengupta, et al. 2006; Lockamy \& McCormack 2004; Gunasekaran, et al. 2001). The second section of the questionnaire included questions about demographics for these firms.

Firms were initially contacted by telephone as this, according to Kopczak (1997), increases the response rate and it also helps the researcher to identify the most appropriate and informed managers in a firm (Van Hoek 2001). Hence, we requested firms to provide us with the "key 
informants" who were able to participate in our survey and possessed expert knowledge of the dairy SCP within their organizations. Considering that many firms in this chain were small and medium sized enterprises (see Table 1), the target "key informants" (apart from breeders who were the farmers themselves) were the general managers. For the larger firms, the target "key informants" were the managers of the firm's dairy sector or business unit (large dairy manufacturers) or the supply chain and store managers (for wholesalers and retailers). Subsequently, we emailed the questionnaire to these "key informants" to allow them to read it carefully and get prepared. Appointments were organised a few days after the initial email in order to conduct the telephone survey at a convenient time for them (Pyke, et al. 2000). Furthermore, these "informants" were happy to suggest other major firms that they collaborate with in the dairy chain. Overall, we are confident that we approached the most appropriate "informants" to evaluate sustainability performance indicators and, by following the above process, we have secured an increased sampling frame and ensured high quality responses (Fynes, et al. 2005).

Finally, we solicited one response from each firm sampled in the survey and data was collected by a professional research agency via the use of a Computer-Aided Personal Interviewing (CAPI) system. A total of 261 questionnaires were answered through telephone surveys. However, eight of them were not usable because significant amounts of data were missing or had outlier responses. The profile of the respondent firms and their characteristics are displayed in Table 1.

\section{"Insert Table 1 here"}




\section{Results}

Table 2 provides a summary of the means and standard deviations for all 19 measurement indicators for sustainability performance of the Greek dairy SC. The results show that regarding efficiency, the producing/ operational/ raw material cost is the higher cost (approximately $50 \%$ of the firm's turnover). Logistics and distribution costs (storage costs, delivery costs and waste) are quite low even though dairy products are highly sensitive and perishable. Profit margin is close to $12 \%$ of firm's turnover. The flexibility indicators have quite high scores (2.49 and 2.75 respectively) and enjoy a moderate performance. On the contrary, the responsiveness indicators show that the dairy chain responds well to market demands (all three indicators have a score $<2$ ). This phenomenon indicates that dairy firms fulfil the pre-arranged transactions but the evidence shows that they are not capable of offering extra products and services to their customers. Hence, in the case of an unforeseen demand change, this underperformance in terms of flexibility could create a bullwhip effect. Responses from the 253 firms show that the Greek dairy chain is supplied with good quality raw material (1.45) and, therefore, good quality products are provided to the local market (1.88). Product conservation time is low (3.24), despite the fact that storage and delivery conditions scored well (1.63). Finally, packaging and consistency in traceability systems have moderate scores (2.39 and 1.97 respectively) but we believe that consistency in following a traceability system should have been higher taking into consideration that this is a food SC. The overall sustainability performance from the firm's point of view and the market's point of view is almost identical (2.13 and 2.16 respectively). Overall, the Greek dairy SC performs quite well according to its members.

\section{"Insert Table 2 here"}


In order to find any significant differences in the performance of the dairy chain members in relation to these sustainability indicators, we performed a one way analysis of variance (ANOVA). ANOVA is a widely used statistically method for investigating statistically significant differences in SCP between groups of firms (see Zhu \& Sarkis 2006; Frohlich \& Westbrook 2001) and the results are given in Table 3.

\section{"Insert Table 3 here"}

The F-statistic results in Table 3 show significant differences in the efficiency performance of these members for producing/ operational/ raw material costs, storage costs and delivery and distribution costs. The producing/ operational/ raw material cost is significantly higher in the first tiers of the chain (breeders: 59.74\% of the firm's turnover, small dairy manufacturers: $60.62 \%$, large dairy manufacturers: $64.00 \%$ ) indicating that these are the stages where the product value is created and the product takes its final form. On the contrary, the tiers closer to the final consumer (wholesaler, retailers, catering) have lower participation in the value creation procedure. Catering companies have the higher storage costs $(10.57 \%$ of the firm's turnover) probably attributable to our sample including mainly catering companies operating at national level, followed by small and large dairy manufacturers $(7.00 \%$ and $6.50 \%$ of the firm's turnover respectively). Wholesalers and retailers have significantly lower storage costs ( $4.55 \%$ and $2.91 \%$ of the firm's turnover respectively) partly due to the sample mainly including national wholesalers and retailers operating in big urban centers with modern logistics systems and processes applied in their operations. This also justifies their low delivery and distribution costs. It is worth highlighting that, on many occasions, small and large dairy manufacturers could be distributing these products directly to wholesale and retail stores too (especially to smaller and medium-sized wholesalers and retailers). Breeders also 
have low storage costs (3.8\% of the firm's turnover) since they keep their product for a very small time period before being purchased by small and large dairy manufacturers. Regarding delivery and distribution costs, small and large dairy manufacturers show high scores (7.31 and 12.33 respectively) as they manage their own distribution channels and collect the raw material (milk) from breeders.

It is also evident that the sustainable elements of the performance of this chain could be improved. For example, the performance during the delivery of dairy products in extra point of sales has significant differences between chain members. As seen in Table 3, wholesalers, large dairy manufacturers and catering companies are more flexible (scores: $2.27 ; 2.00$ and 2.19 respectively) since they have higher delivery capabilities in their operations. The above members also perform better when responding to the arranged point of sale (scores: 1.56, 1.23 and 1.38 respectively) primarily due to the same reason.

Members of the Greek dairy SC appear very satisfied with the quality of their raw material (mean value $=1.45)$. Between the two chain members that process raw material (small and large dairy manufacturers), large dairy manufacturers evaluate significantly higher their supplies in milk (score: 1.08) than small dairy manufacturers (score: 1.53). One plausible explanation is that large dairy manufacturers have greater influence in the chain due to their size and their ability to purchase significant quantities of milk and, hence, they can have access to the best quality. A crucial element in SCP regarding quality is product conservation time which, on average, was the worst performing sustainability indicator (score: 3.24 , see Table 2). Breeders have the second poorest score (4.00) since they have inferior storage capabilities and they must sell their product almost immediately to dairy manufacturers (Table 3). The results indicate that the small dairy manufacturers enjoy a better product conservation 
time (score: 2.50 ). The fact that manufacturers are processing raw material possibly lengthens product conservation time. Then moving further down the chain, the specific indicator deteriorates significantly where wholesalers perform better than retailers and retailers perform better than catering companies (scores: $2.93,3.37$ and 4.78 respectively). In addition, large dairy manufacturers perform significantly worse (score: 3.77 ) than small dairy manufacturers. This is probably explained by the fact that most large dairy manufacturers produce primarily fresh milk which has a very limited lifetime whilst small manufacturers produce mostly cheese that has a longer lifetime. Moreover, small and large dairy manufacturers are the chain members responsible for product packaging (scores: 1.80 and 1.62 respectively). The scores of the other chain members are all above 2.00. Large dairy manufacturers and catering companies are the chain members that evaluated their own sustainability performance as satisfactory (scores: 1.46 and 1.81 respectively).

In addition, we analysed each member of the chain regarding their sustainability performance by using a one sample T-test. Using the T-test analysis we discovered statistically significant differences between a single chain member and the whole chain in terms of the sustainability indicators. The one sample T-test allows us to use the average sustainability performance scores of the whole dairy chain as a comparison basis for discovering the specific areas where a chain member performs significantly better or worse than the average for the chain. It is a widely used methodology in the SCP field and it has been used in past studies for comparing SCP between groups (Simatupang \& Sridharan 2005; Ramdas \& Spekman 2000).

\section{"Insert Table 4 here"}

Table 4 exhibits the key differences in relation to breeders' performance. Breeders' delivery and distribution cost is significantly lower (score: 3.31 ) than the average chain cost (mean 
score: 6.12 ). As a result, this specific cost rolls over to the next chain tiers considering that small and large dairy manufacturers collect milk from breeders. Producing/ operational/ raw material cost is significantly higher (score: 60.62) for small dairy manufacturers (see Table 4) indicating that there are more value adding procedures in manufacturers' operations. They also manage product conservation time (score: 2.50 ) and they package products (score: 1.80 ) better than the whole chain on average. As a result, the next tiers don't contribute considerably to packaging. Table 4 clearly shows that the large dairy manufacturers perform very satisfactorily in terms of sustainability indicators. In particular, they respond better in delivering the products in the arranged point of sale (score: 1.23) but also in delivering the ordered products (score: 1.23). They manage to supply their production with the best raw material (score: 1.08) and they show greater consistency in following a traceability system (score: 1.08). Their storage and delivery conditions are also better (score: 1.15) than the average for the chain (mean: 1.63). The sustainable performance of the large dairy manufacturers is evaluated much higher (scores 1.46 and 1.62) than the chain average (means scores: 2.13 and 2.16 respectively). It is evident from Table 4 that wholesalers underperform in terms of profit margin (score: 7.76) and they exhibit lower producing/ operational/ raw material cost (score: 35.26 ) and financial cost (score: 6.25 ). The only indicator where wholesalers perform better than the chain average (mean score: 2.75 ) is the flexibility in delivering to extra points of sales (score: 2.27). This is not surprising as most wholesalers (especially those delivering to smaller retailers and small companies) need to deliver under a flexible manner to various locations as required and they could have developed such a skill. The key differences between retailers' sustainable performance and the average sustainable performance of the chain are also presented in Table 4 where retailers have a lower logistics cost (storage cost: 2.91 ; delivery and distribution cost: 2.91 and waste: 2.76 respectively) than the chain on average (means scores: $5.63 ; 6.14$ and 3.94 respectively). This indicates that 
retailers have a low contribution in the product distribution of the SC. In addition, they underperform in delivery flexibility and packaging. Their underperformance in packaging is not surprising either, as packaging could deteriorate by the time it reaches retailer's shelves as, until then, it could have been transported and stored in various locations for other chain members. Catering companies over-perform in the issues of flexibility and responsiveness (Table 4). Even though their flexibility scores are above 2.00 (2.04 and 2.19), they are significant lower than the chain average (2.49 and 2.75). This is due to the nature of their business that deals with smaller and fast deliveries and, hence, they need to have in place such delivery capabilities. That also influences their responsiveness and this could explain why the total evaluation of the sustainable performance of catering firms is better (score: 1.81) than the chain average (mean: 2.13).

\section{Discussion}

In this paper, we conducted a comparative analysis of Greek dairy chain members in relation to sustainability performance indicators. This analysis illustrated many major performance differences between members of this chain. Specifically, significant differences were noted primarily in connection with producing / operational / raw material cost, storage costs, delivery and distribution costs, flexibility in the delivery to extra point of sales, product conservation time and quality of my firm's products packaging (Table 3). These differences are attributed to many reasons. For example, in relation to efficiency performance indicators, it is evident that most product value is created by small and large dairy manufacturers (producing/operational/raw material cost indicator). Equally, small and large dairy manufacturers are responsible for many product storage, delivery and distribution costs in the Greek dairy SC as they manage products in most stages of that chain (e.g. the collection of milk from breeders to delivery of final product to wholesale, retail and catering outlets). There 
is also strong evidence for a performance gap between the flexibility performance of retailers and breeders with the flexibility performance of the rest of the chain. Breeders are not producing the raw material as required whilst retailers seem to rely only on selling the products to consumers. Product conservation time is another point with a sustainability performance gap being apparent, especially for catering firms and small dairy manufacturers ( 2.50 for small dairy manufacturers and 4.78 for catering firms). This could be attributed to a lack of cooperation between members of the whole chain considering the low scores that breeders exhibit and the subsequent "snowball effect" that this may affect the chain as a whole. This lack of cooperation between chain members is well-documented in the food SCM literature [see Fearne (1998) for the UK beef chain; Van der Vorst (2006) for other national food chains] but it is also discussed extensively in the "generic" (non-food) marketing and SCM literature [see relevant theoretical paper by Ballou, et al. (2000) and Tan (2006) who examined various SCs representing sectors such as textile, furniture, chemicals and tobacco to name a few]. Major sustainability performance differences were also noted in relation to “quality of my firm’s products packaging”. Here, both small and large manufacturers performed much better than the remaining SC members and this indicates that the quality of packaging deteriorates as the food product progresses through the downstream stages of the chain. Finally, there is a gap in the total firm's sustainability performance between most SC members and large dairy manufacturers as these SC members cannot achieve the same sustainability performance standards as the large manufacturers. Therefore, the above have addressed succinctly the first research question: Are there any major differences in the SC sustainability performance between the key members of the Greek dairy chain?

In terms of the second research question (Against which sustainability performance indicators do these members over-perform or underperform and what is the impact of their performance 
on the rest of the chain?), our work has highlighted the key role of the large dairy manufacturers in this chain. These manufacturers are responsible for value creation through production, make a large contribution to the product distribution and logistics and are more flexible and responsive in these operations. Large dairy manufacturers are also the key members for the implementation of traceability as well as leading the whole chain in that implementation and putting pressure on other members to follow. Overall, the results indicate that the large dairy manufacturers are the "sustainability performance champions" in the chain followed by catering firms and wholesalers (Table 4). This is a key finding considering that, over the past few decades, we have witnessed the pivotal role of retailers in many "generic", non-food chains (Towill 1992) as well as in many national food chains (see Dawson 2004). Some of these authors have also used specific phrases such as "chain champions" and "channel captains" (see Smith 2006) to illustrate the dominant, powerful role of retailers in the chain. Despite this, the large manufacturers seem to be the key performers in relation to sustainability. However, the overall high performance of the large manufacturers could give a rather false performance image for the whole chain as it improves the average scores whilst, at the same time, some chain members are underperforming. Specifically, breeders underperform in few key indicators including product conservation time, flexibility in delivery to extra point of sales and total evaluation of firm's performance. This is not a surprising result as producers have been the weak link (member) in most national food chains in terms of many key issues including performance (see Fearne 1998).

This underperformance creates major concerns for the overall sustainability performance of this chain and it is related to our third research question: How does the Greek dairy chain perform in terms of the major sustainability indicators? We have shown that this chain is influenced largely by the strong performance of a few members (especially by the large 
manufacturers) while the remaining members will have to improve their performance and support the chain towards achieving enhanced sustainability credentials. Specifically, the delivery capabilities of catering firms, wholesalers and large dairy manufacturers contribute to the improvement of responsiveness and flexibility of the average scores for the chain. These should be the "benchmark" cases for the rest of the chain members in order to achieve higher flexibility and responsiveness performance. The poor performance of most members regarding product conservation time worsens the performance of the chain in this specific indicator. The latter supports the findings of Molnar \& Gellynk (2009) that when some members of a food chain perform more poorly than others, then the whole chain's performance deteriorates. A similar finding is proposed by Zhao, et al. (2002) for other "generic", non-food chains regarding the influential role of information sharing and ordering co-ordination by chain members on the total SC performance. Therefore, a higher level of cooperation and coordination in product conservation time between all members is essential to achieve sustainable performance as this will have an impact on the quality of the final dairy products; however, we anticipate that it will be challenging to achieve this [see Fearne (1998) for the lack of co-operation and co-ordination in the UK food chain; Van der Vorst (2006) for other national food chains; Zhao, et al. (2002); Ballou, et al. (2000); Tan (2006) for other "generic", non-food chains]. In addition, the positive performance of the dairy chain in traceability is partly explained by the strong performance of the large dairy manufacturers who lead the chain on this indicator. More importantly, the other five chain members should minimize the performance gap in this sustainability indicator in order to secure the future viability and sustainability of the chain. On the other hand, this chain demonstrates strong sustainability performance in relation to raw materials' quality largely due to the heightened performance of the large and small manufacturers (Table 3). In terms of the total sustainability performance evaluation, large dairy manufacturers and catering firms improve 
the average scores of the chain resulting in an improved sustainability performance for the chain as a whole.

Finally, it is worth pointing out that the last two measures (total evaluation of firm's sustainability performance; and total evaluation of firm's sustainability performance from the market's point of view) seem to reflect our findings for the other measures as the large manufacturers achieved the best scores. This also confirms the objectivity of our work as we have reliable findings based on honest perceptions by the "key informants".

\section{Conclusions, managerial implications and future research}

In the past few years, many marketing scholars have stressed the need for integration between the marketing and operations domains (Karmarkar 1996). Aiming to address this, Malhotra \& Sharma (2002) proposed an integrative framework between these two domains and called for further research in relation to firm performance focusing on SC issues. Our study has contributed to the marketing literature in general, and to the work by Karmarkar (1996), and Malhotra \& Sharma (2002) in particular, by formulating and empirically testing an interdisciplinary sustainability framework where, under the lens of SCM, a plethora of marketing and operations, sustainability-related indicators were integrated.

For the latter, it is important to note that sustainability performance measurement has been an uncharted territory as there has been a distinct lack of empirical work in the extant literature (see for example, Bititci, et al. 2012 for the lack of relevant work in the business and management literature including the marketing, operations management and SCM literature). More specifically, this literature lacks empirical studies where the analysis focuses on supply chain-wide sustainability and employs appropriate indicators (Pagell \& Wu 2009; Rao \& Holt 
2005). To our knowledge, this is the first study that monitors the sustainability performance of the whole SC by examining all key chain members in the evaluation. Hence, we follow an inter-organizational, supply chain-wide approach that has been highly recommended by many marketing and operations management researchers in the past (see Ballou, et al. 2000; Gunasekaran, et al. 2004; Jüttner, et al. 2010; Van der Vorst 2006). In addition, our work has contributed to the marketing, operations management and SCM literature regarding the performance of a SC and its key members by following the use of a specific set of marketing and operations, sustainability-related indicators.

Furthermore, our empirical work has generated many unique and original results. A major result is that large manufacturers were found to be the "sustainability performance champions". This presents a key contribution to the current marketing literature considering that most marketing researchers have noted the powerful role of retailers in most supply chains (see Kumar 1996; Kadiyali, et al. 2000; Geylani, et al. 2007). Hence, it may have been expected that retailers will command a key role in the Greek dairy chain too by being the "champions" in relation to sustainability implementation; instead, we noted that large manufacturers lead most sustainability initiatives (e.g. traceability).

The latter presents a policy implication as the experience of large manufacturers dealing with sustainability should be captured by policy makers and relevant stakeholders. We believe that large manufacturers could have a central role in national sustainability forums, industry and supply chain meetings and, overall, they could assume a greater responsibility in relation to the implementation of sustainability issues. 
In addition, our work has generated many insights that will be of interest to managers operating in food and non-food chains from various national environments. For example, we are confident that our framework and the developed sustainability performance indicators can be used by managers in their attempt to achieve sustainability in business operations. Equally, the results of this work provide a starting point and an initial benchmark for managers of the Greek dairy sector in particular as we have identified the best (e.g. large manufacturers, catering firms, wholesalers in this order) and worst performers (e.g. breeders) and their strengths and weaknesses. Hence, managers representing the weak links / worst performers of this SC should make detailed use of our key performance indicators (KPIs) to improve their firm's operations radically in specific areas and managers from the best performers should share their sustainability-related knowledge and expertise and disseminate their best sustainability practices accordingly.

A concerning finding for the whole SC relates to poor product conservation time where urgent action is needed by all SC members. Product conservation time emanates from poor operational practices and we identified low quality of product packaging and limited use of traceability in this chain followed by many of its members. The poor product conservation time could create major consumer concerns for product quality and safety and, subsequently, it is a prime example of how the operations and marketing domains are integrated and interrelated in our work. Therefore, managers need to think creatively if they want to capture these interrelationships between various indicators in relation to sustainability performance and, at the same time, they need to focus and prioritise their efforts on specific KPIs and excel in them if they aim to achieve superior sustainability performance in their firms. The latter will also depend on, inter alia, the sustainability challenges which managers need to tackle, emanating from their firm (micro level), or the sector, industry, supply chain (meso level) and 
the national or global environment (macro level) in which they operate. Overall, managers need to formulate an integrated, holistic sustainability plan encompassing most firm functions (intra-firm approach) and, on that basis, they need to work together with senior managers from key functions including marketing, operations, SCM, finance and information technology to name a few. To conclude, we advocate that managers (and other stakeholders including policy makers) could follow the approach implemented in our work where we employed a sustainability framework and made use of marketing and operations, sustainability-related indicators in an interdisciplinary and overarching fashion.

The above presents an opportunity for future research, as a multi-faceted, integrative sustainability framework could be further developed incorporating other domains (apart from marketing, operations management, SCM). Our framework is the first study in that direction and we are confident that it can be equally tested in most food and non-food chains operating in other national environments albeit with some modifications, required to capture other sectors' and countries' SC-related specificities. Future research could also examine which SC members are the "sustainability performance champions" in other national, food and non-food chains and could shed further light on our finding that highlighted the major role of large manufacturers in that respect.

Last but not least, there are a few limitations to this study. We used a limited number of sustainable performance indicators and further research is needed to substantiate our findings. Moreover, we invited managers from the respondent firms to self evaluate the SCP of their firm and it is possible that the results suffer from respondent bias. 


\section{Acknowledgements}

This study was funded by the European Union and was part of the project "Systems of Entrepreneurial guiding of agricultural enterprises in the zones of tobacco plantations with an orientation on their viability and competitiveness".

\section{$\underline{\text { References }}$}

Angell, L. C., \& Klassen, R. D. (1999). Integrating environmental issues into the mainstream: an agenda for research in operations management. Journal of Operations Management, 17 (5), 575-598.

Aramyan, L. H., Lansink, A. G. J. M. O., van der Vorst, J. G. A. J., \& van Kooten, O. (2007). Performance measurement in agri-food supply chains: a case study. Supply Chain Management: An International Journal, 12 (4), 304-315.

Aramyan, L., Ondersteijn, C., van Kooten, O., \& Lansink, A. G. J. M. O. (2006). Performance indicators in agri-food production chains, in Quantifying the agri-food supply chain, Christien J. M. Ondersteijn, Jo H. M. Wijnands, Ruud B. M. Huirne, and Olaf van Kooten, eds., Springer, Dordrecht

Ballou, R. H., Gilbert, S. M., \& Mukherjee, A. (2000). New managerial challenges from supply chain opportunities. Industrial Marketing Management, 29 (1), 7-18.

Bititci, U., Garengo, P., Dörfler, V., \& Nudurupati, S. (2012). Performance measurement: challenges for tomorrow. International Journal of Management Reviews, 14 (3), 305-327. Boyer, K. K., \& Hult, G. T. M. (2005). Extending the supply chain: integrating operations and marketing in the online grocery industry. Journal of Operations Management, 23 (6), 642661.

Brown, K. A. (1996). Workplace safety: a call for research. Journal of Operations Management, 14 (2), 157-171. 
Carter, C. R., \& Dresner, M. (2001). Purchasing's role in environmental management: crossfunctional development of grounded theory. Journal of Supply Chain Management, 37 (3), $12-27$.

Carter, C. R., \& Rogers, D. S. (2008). A framework of sustainable supply chain management: moving toward new theory. International Journal of Physical Distribution and Logistics Management, 38 (5), 360-387.

Carter, C. R., Ellram, L. M., \& Tate, W. L. (2007). Structure and influence: a logistics management application of social network analysis. Journal of Business Logistics, 28 (1), $137-168$.

Carter, C. R., Kale, R., \& Grimm, C. M. (2000). Environmental purchasing and firm performance: an empirical investigation. Transportation Research, Part E, 36 (3), 219-228. Chabowski, B. R., Mena, J. T., \& Gonzalez-Padron, T. L. (2011). The structure of sustainability research in marketing, 1958-2008: a basis for future research opportunities. Journal of Academy of Marketing Science, 39 (1), 55-70.

Chen, I. J., \& Paulraj, A. (2004). Towards a theory of supply chain management: the constructs and measurements. Journal of Operations Management, 22 (2), 119-150. Chow, W. S., Madu, C. N., Kuei, C. H., Lu, M. H., Lin, C., \& Tseng, H. (2008). Supply chain management in the US and Taiwan: An empirical study. Omega, 36 (5), 665-679.

Coley, D., Howard, M., \& Winter, M. (2009). Local food, food miles and carbon missions: a comparison of farm shop and mass distribution approaches. Food Policy, 34 (2), 150-155. Dabenne, F., \& Gay, P. (2001). Food traceability systems: performance evaluation and optimization. Computers and Electronics in Agriculture, 75 (1), 139-146.

Dawson, J. (2004). Food retailing, wholesaling and catering, in Food supply chain management, Michael. A. Bourlakis and Paul W. H. Weightman, eds., Blackwell / Wiley, Oxford. 
Ellinger, A. E. (2000). Improving marketing / logistics cross-functional collaboration in the supply chain. Industrial Marketing Management, 29 (1), 85-96.

Fearne, A. (1998). The evolution of partnerships in the meat supply chain: insights from the British beef industry. Supply Chain Management: An International Journal, 3 (4), 214-231. Frederick, W. C. (1960). The growing concern over business responsibility. California Management Review, 2 (4), 54-61.

Frohlich, M. T., \& Westbrook, R. (2001). Arcs of integration: an international study of supply chain strategies. Journal of Operations Management, 19 (2), 185-200.

Fynes, B., Voss, C., \& de Búrca, S. (2005). The impact of supply chain relationship dynamics on manufacturing performance. International Journal of Operations \& Production Management, 25 (1), 6-19.

Gerbens-Leenes, P. W., Moll, H. C., \& Uiterkamp, A. J. M. S. (2003). Design and development of a measuring method for environmental sustainability in food production systems. Ecological Economics, 46 (2), 231-248.

Geylani, T., Dukes, A. J., \& Srinivasan, K. (2007). Strategic manufacturer response to a dominant retailer. Marketing Science, 26 (2), 164-178.

Gunasekaran, A., Patel, C., \& Mc Gaughey, R. E. (2004). A framework for supply chain performance measurement. International Journal of Production Economics, 87 (3), 333-347. Gunasekaran, A., Patel, C., \& Tirtiroglu, E. (2001). Performance measures and metrics in a supply chain environment. International Journal of Operations and Production Management, 21 (1/2), 71-87.

Hall, J. (2000). Environmental supply chain dynamics. Journal of Cleaner Production, 8 (6), 455-471.

Handfield, R. B., Walton, S. V., Seegers, L. K., \& Melnyk, S. A. (1997). 'Green’ value chain practices in the furniture industry. Journal of Operations Management, 15 (4), 293-315. 
Heller, M. C., \& Keoleian, G. A. (2003). Assessing the sustainability of the US food system: a life cycle perspective. Agricultural Systems, 76 (3), 1007-1041.

Holmes, S. M., Power, M. L., \& Walter, C. K. (1996). A motor carrier wellness program: development and testing. Transportation Journal, 35 (3), 33-48.

ICAP (2011) Greek dairy industry, Athens, Greece.

Ilbery, B., \& Maye, D. (2005). Food supply chains and sustainability: evidence from specialist food producers in the Scottish/English borders. Land Use Policy, 22 (4), 331-344. Jüttner, U., Christopher, M., \& Baker, S. (2010). Demand chain management-integrating marketing and supply chain management. Industrial Marketing Management, 36 (3), 377-392. Kadiyali, V., Chintagunta, P., \& Vilcassim, N. (2000). Manufacturer-retailer channel interactions and implications for channel power: an empirical investigation of pricing in a local market. Marketing Science, 19 (2), 127-148.

Karmarkar, U. S. (1996). Integrative research in marketing and operations management. Journal of Marketing Research, 33 (2), 125-133.

Keeble, J. J., Topiol, S., \& Berkeley, S. (2003). Using indicators to measure sustainability performance at a corporate and project level. Journal of Business Ethics, 44 (2-3), 149-158. Klassen, R. D. (1993). Integration of environmental issues into manufacturing. Production and Inventory Management Journal, 34 (1), 82-88.

Klassen, R. D., \& Mc Laughlin, C. P. (1996). The impact of environmental management on firm performance. Management Science, 42 (8), 1199-1214.

Kolk, A. (2004). A decade of sustainability reporting: developments and significance. International Journal of Environment and Sustainable Development, 3 (1), 51-64.

Kopczak, L. R. (1997). Logistics partnerships and supply chain restructuring: survey results from the U.S. computer industry. Production and Operations Management, 6 (3), 226-247. 
Kumar, N. (1996). The power of trust in manufacturer-retailer relationships. Harvard Business Review, 74 (6), 92-106.

Lai, K.H., Ngai, E. W. T., \& Cheng, T. C. E. (2002). Measures for evaluating supply chain performance in transport logistics. Transportation Research Part E, 38 (6), 439-456.

Lambert, D. M., \& Cooper, M. C. (2000). Issues in supply chain management. Industrial Marketing Management, 29 (1), 65-83.

Lewis, H. (2005). Defining product stewardship and sustainability in the Australian packaging industry. Environmental Science \& Policy, 8 (1), 45-55.

Lockamy III, A., \& Mc Cormack, K. (2004). Linking SCOR planning practices to supply chain performance: an exploratory study. International Journal of Operations and Production Management, 24 (12), 1192-1218.

Malhotra, M. K., \& Sharma, S. (2002). Spanning the continuum between marketing and operations. Journal of Operations Management, 20 (3), 209-219.

Maloni, M. J., \& Brown, M. E. (2006). Corporate social responsibility in the supply chain: an application in the food industry. Journal of Business Ethics, 68 (1), 35-52.

Matopoulos, A., \& Bourlakis, M. (2010). Sustainability practices and indicators in food retail logistics: findings from an exploratory study. Journal of Chain and Network Science, 10 (3), 207-218.

Mc Elroy, J. C., Rodriguez, J. M., Griffin, G. C., Morrow, P. C., \& Wilson, M. G. (1993). Career stage, time spent on the road, and truckload driver attitudes. Transportation Journal, $33(1), 5-14$.

Mentzer, J. T., De Witt, W., Keebler, J. S., Min, S., Nix, N. W., Smith, C. D., \& Zacharia, Z. G. (2001). Defining supply chain management. Journal of Business Logistics, 22 (2), 1-25. 
Molnar, A., \& Gellynk, X. (2009). Performance imbalances in the chain: EU traditional food sector. Proceedings of the $4^{\text {th }}$ Aspects and Visions of Applied Economics and Informatics, Debrecen, Hungary.

Pagell, M., \& Wu, Z. (2009). Building a more complete theory of sustainable supply chain management using case studies of ten exemplars. Journal of Supply Chain Management, 45 (2), 37-56.

Persson, F., \& Olhager, J. (2002). Performance simulation of supply chain designs. International Journal of Production Economics, 77 (3), 231-245.

Pyke, D., Robb, D., \& Farley, J. (2000). Manufacturing and supply chain management in China: a survey of state-, collective-, and privately-owned enterprises. European Management Journal, 18 (6), 577-589.

Ramdas, K., \& Spekman, R. E. (2000). Chain or shackles: understanding what drives supply chain performance. Interfaces, 30 (4), 3-21.

Rao, P., \& Holt, D. (2005). Do green supply chains lead to competitiveness and economic performance? International Journal of Operations \& Production Management, 25 (9), 898916.

Sarkis, J. (2001). Manufacturing's role in corporate environmental sustainability: concerns for the new millennium. International Journal of Operations \& Production Management, 21 (5/6), 666-686.

Sengupta, K., Heiser, D. R., \& Cook, L. S. (2006). Manufacturing and service supply chain performance. The Journal of Supply Chain Management, 42 (4), 4-15.

Seuring, S., \& Müller, M. (2008). From a literature review to a conceptual framework for sustainable supply chain management. Journal of Cleaner Production, 16 (15), 1699-1710. 
Shepherd, C., \& Gunter, H. (2006). Measuring supply chain performance: current research and future directions. International Journal of Productivity and Performance management, 55 (3/4), 242-258.

Shrivastava, P. (1995). Environmental technologies and competitive advantage. Strategic Management Journal, 16, 183-200.

Simatupang, T. M., \& Sridharan, R. (2005). The collaboration index: a measure for supply chain collaboration. International Journal of Physical Distribution \& Logistics Management, $35(1), 44-62$.

Smith, D. L. G. (2006). The role of retailers as channel captains in retail supply chain change: the example of Tesco. PhD thesis, Stirling Management School, University of Stirling, Scotland, United Kingdom.

Tan, K. C. (2006). Supply chain management: practices, concerns, and performance issues. Journal of Supply Chain Management, 38 (1), pp. $42-53$.

Towill, D. R. (1992). Supply chain dynamics - the change engineering challenge of the mid 1990s. Journal of Engineering Manufacture, 206 (4), 233-245.

Tracey, M., Lim, J. S., \& Vonderembse, M. A. (2005). The impact of supply-chain management capabilities on business performance. Supply Chain Management: An International Journal, 10 (3), 179-191.

Trienekens, J., van Uffelen, R., Debaire, J., \& Omta, O. (2008). Assessment of innovation and performance in the fruit chain. British Food Journal, 110 (1), 98-127.

Van der Vorst, J. G. A. J. (2006). Performance measurement in agri-food supply chain networks, in Quantifying the agri-food supply chain, Christien J. M. Ondersteijn, Jo H. M. Wijnands, Ruud B. M. Huirne, and Olaf van Kooten, eds., Springer, Dordrecht. 
Van der Vorst, J. G. A. J., Tromp, S. C., \& van der Zee, D. J. (2009). Simulation modelling for food supply chain redesign; integrated decision making on product quality, sustainability and logistics. International Journal of Production Research, 47 (23), 6611-6631.

Van der Vorst, J. G. A. J., van Dijk, S. J., \& Beulens, A. J. M. (2001). Supply chain design in the food industry. International Journal of Logistics Management, 12 (2), 73-86.

Van Hoek, R. I. (2001). The contribution of performance measurement to the expansion of third party logistics alliances in the supply chain. International Journal of Operations and Production Management, 21 (1/2), 15-29.

Zhao, X., Xie, J., \& Zhang, W. J. (2002). The impact of information sharing and ordering coordination on supply chain performance. Supply Chain Management: An International Journal, 7 (1), 24-40.

Zhu, Q., \& Sarkis, J. (2006). An inter-sectoral comparison of green supply chain management in China: drivers and practices. Journal of Cleaner Production, 14 (5), 472-486.

Zhu, Q., Sarkis, J., \& Lai, K. H. (2008). Confirmation of a measurement model for green supply chain management practices implementation. International Journal of Production Economics, 111 (2), 261-273.

Ziggers, G. W., \& Trienekens, J. (1999). Quality assurance in food and agribusiness supply chains: developing successful partnerships. International Journal of Production Economics, 60-61, 271-279. 


\section{TABLES}

Table 1: Profile of the respondent firms

\begin{tabular}{|c|c|c|c|c|c|c|}
\hline $\begin{array}{l}\text { Type of firm } \\
(\mathrm{N}=253) \text { and }\end{array}$ & Breeders & $\begin{array}{c}\text { Small dairy } \\
\text { manufacturers }\end{array}$ & $\begin{array}{c}\text { Large dairy } \\
\text { manufacturers } 1\end{array}$ & Wholesalers & Retailers & $\begin{array}{l}\text { Catering } \\
\text { firms }\end{array}$ \\
\hline $\begin{array}{c}\% \text { of whole } \\
\text { chain) }\end{array}$ & $\begin{array}{c}26 \\
(10,28 \%)\end{array}$ & $\begin{array}{c}67 \\
(26,48 \%)\end{array}$ & $\begin{array}{c}11 \\
(5,14 \%)\end{array}$ & $\begin{array}{c}70 \\
(27,67 \%)\end{array}$ & $\begin{array}{c}53 \\
(20,95 \%)\end{array}$ & $\begin{array}{c}26 \\
(10,28 \%)\end{array}$ \\
\hline $\begin{array}{l}\text { Number of } \\
\text { employees } \\
\text { (Mean) }\end{array}$ & $\begin{array}{c}\text { Family- } \\
\text { based }\end{array}$ & 45 & 28 & 17 & $426^{2}$ & 27 \\
\hline $\begin{array}{l}\text { Level of } \\
\text { turnover } \\
\text { (more } \\
\text { frequent } \\
\text { responses in } \\
\text { relevant } \\
\text { groups) }\end{array}$ & $\begin{array}{l}30.000- \\
40.000^{3}\end{array}$ & $\begin{array}{c}500.000- \\
1.000 .000\end{array}$ & $>1.000 .000$ & $>1.000 .000$ & $\begin{array}{c}200.000- \\
500.000\end{array}$ & $\begin{array}{l}500.000- \\
1.000 .000\end{array}$ \\
\hline $\begin{array}{l}\text { Size of } \\
\text { warehouses } \\
\text { (Mean) }\end{array}$ & $74,6^{4}$ & 1.522 & 1.678 & 1.450 & 718 & 1.109 \\
\hline $\begin{array}{c}\text { Number } \\
\text { of trucks } \\
\text { (Mean) }\end{array}$ & $4^{5}$ & 7 & 11 & 8 & 7 & 5 \\
\hline \multicolumn{7}{|c|}{$\begin{array}{c}\text { Notes: 1: The number of large dairy manufacturers is low but they show a significantly } \\
\text { different behaviour from the other chain members, 2: The large average number of employees } \\
\text { stems from the fact that large retailers are included in the sample, 3: Annual income (euros), } \\
\text { 4: Farm size in hectares, 5: Number of agricultural trucks }\end{array}$} \\
\hline
\end{tabular}


Table 2: Sustainability performance of the Greek dairy supply chain

\begin{tabular}{|c|c|c|c|}
\hline $\begin{array}{l}\text { Sustainability } \\
\text { Performance indicator }\end{array}$ & $\begin{array}{l}\text { Score } \\
\text { Mean (SD) } \\
(\mathrm{N}=253)\end{array}$ & $\begin{array}{l}\text { Sustainability } \\
\text { indicator }^{2}\end{array}$ & $\begin{array}{l}\text { Score } \\
\text { Mean (SD) } \\
(\mathrm{N}=253)\end{array}$ \\
\hline \multirow[b]{2}{*}{$\begin{array}{l}\text { Producing/ operational/ } \\
\text { raw material cost }\end{array}$} & \multirow[b]{2}{*}{$\begin{array}{c}49,33 \\
(29,70)\end{array}$} & Flexibility in extra volume orders & $2,49(1,54)$ \\
\hline & & $\begin{array}{l}\text { Flexibility in delivering to extra } \\
\text { points of sales }\end{array}$ & $2,75(1,76)$ \\
\hline \multirow{2}{*}{ Gross profit margin } & \multirow{2}{*}{$\begin{array}{c}11,84 \\
(10,64)\end{array}$} & $\begin{array}{c}\text { Responsiveness in the arranged lead } \\
\text { time }\end{array}$ & $1,61(0,91)$ \\
\hline & & $\begin{array}{l}\text { Responsiveness in delivering to the } \\
\text { arranged point of sale }\end{array}$ & $1,76(1,30)$ \\
\hline \multirow[t]{2}{*}{ Storage cost } & \multirow[t]{2}{*}{$5,68(7,66)$} & $\begin{array}{c}\text { Responsiveness in delivering the } \\
\text { ordered type of product (exact code, } \\
\text { quality, etc) }\end{array}$ & $1,62(0,94)$ \\
\hline & & Raw materials' quality ${ }^{3}$ & $1,45(0,69)$ \\
\hline \multirow{2}{*}{$\begin{array}{c}\text { Delivery and distribution } \\
\text { cost }\end{array}$} & \multirow{2}{*}{$6,12(7,95)$} & Quality of my firm's product & $1,88(1,66)$ \\
\hline & & Product conservation time & $3,24(1,98)$ \\
\hline \multirow[t]{2}{*}{ Waste } & \multirow[t]{2}{*}{$3,89(4,05)$} & $\begin{array}{l}\text { Show consistency in following a } \\
\text { traceability system }\end{array}$ & $1,97(1,54)$ \\
\hline & & Storage and delivery conditions & $1,63(1,12)$ \\
\hline \multirow{3}{*}{ Financial cost } & \multirow{3}{*}{$9,64(13,29)$} & $\begin{array}{l}\text { Quality of my firm's products } \\
\text { packaging }\end{array}$ & $2,39(1,89)$ \\
\hline & & $\begin{array}{c}\text { Total evaluation of firm's } \\
\text { sustainability performance } \\
\end{array}$ & $2,13(0,97)$ \\
\hline & & $\begin{array}{c}\text { Total evaluation of firm's } \\
\text { sustainability performance from the } \\
\text { market's point of view }\end{array}$ & $2,16(1,00)$ \\
\hline \multicolumn{4}{|c|}{$\begin{array}{l}\text { Notes: 1:percentage of turnover, 2:Seven point Likert scale (lower values indicate better } \\
\text { sustainable performance), 3: the question concerns only small dairy manufacturers and } \\
\text { large dairy manufacturers, *: The indicators do not sum 100\% of the turnover since we } \\
\text { measure different dimensions (costs and gross profit margin) and there could be other } \\
\text { costs which their measurement exceeds the purpose of this study. }\end{array}$} \\
\hline
\end{tabular}


Table 3: Differences within the sustainability performance of dairy chain members

\begin{tabular}{|c|c|c|c|c|c|c|c|}
\hline $\begin{array}{l}\text { Sustainability } \\
\text { Performance } \\
\text { indicator }\end{array}$ & $\begin{array}{c}\text { Breeders } \\
\text { Mean(SD) } \\
(\mathrm{N}=26) \\
\end{array}$ & $\begin{array}{c}\text { Small } \\
\text { dairy } \\
\text { manufa- } \\
\text { cturers } \\
\text { Mean(SD) } \\
(\mathrm{N}=67)\end{array}$ & $\begin{array}{c}\text { Large } \\
\text { dairy } \\
\text { manufa- } \\
\text { cturers } \\
\text { Mean(SD) } \\
(\mathrm{N}=11)\end{array}$ & $\begin{array}{c}\text { Wholesalers } \\
\text { Mean(SD) } \\
(\mathrm{N}=70)\end{array}$ & $\begin{array}{c}\text { Retailers } \\
\text { Mean(SD) } \\
(\mathrm{N}=53) \\
\end{array}$ & $\begin{array}{l}\text { Catering } \\
\text { firms } \\
\text { Mean }(\mathrm{SD} \\
)(\mathrm{N}=26)\end{array}$ & $\begin{array}{c}\text { ANOVA } \\
\text { F-statistic } \\
\end{array}$ \\
\hline $\begin{array}{c}\text { Producing/ } \\
\text { operational/ raw } \\
\text { material cost }^{1}\end{array}$ & $\begin{array}{c}59,74 \\
(25,14)\end{array}$ & $\begin{array}{c}60,62 \\
(24,98)\end{array}$ & $\begin{array}{c}64,00 \\
(28,81)\end{array}$ & $\begin{array}{c}35,26 \\
(32,94)\end{array}$ & $\begin{array}{c}46,12 \\
(32,14)\end{array}$ & $\begin{array}{c}32,07 \\
(15,18)\end{array}$ & 5,140 \\
\hline Storage $\cos \mathrm{t}^{1}$ & $\begin{array}{c}3,80 \\
(6,57)\end{array}$ & $\begin{array}{c}7,00 \\
(9,30)\end{array}$ & $\begin{array}{c}6,50 \\
(4,36)\end{array}$ & $\begin{array}{c}4,55 \\
(4,99)\end{array}$ & $\begin{array}{c}2,91 \\
(3,56)\end{array}$ & $\begin{array}{c}10,57 \\
(11,15)\end{array}$ & 2,408 \\
\hline $\begin{array}{c}\text { Delivery and } \\
\text { distribution cost }^{1}\end{array}$ & $\begin{array}{c}3,31 \\
(5,13)\end{array}$ & $\begin{array}{c}7,31 \\
(8,29)\end{array}$ & $\begin{array}{c}12,33 \\
(15,37)\end{array}$ & $\begin{array}{c}5,66 \\
(7,36)\end{array}$ & $\begin{array}{c}2,91 \\
(2,89)\end{array}$ & $\begin{array}{c}10,71 \\
(11,66)\end{array}$ & 2,846 \\
\hline $\begin{array}{c}\text { Flexibility in } \\
\text { delivering to extra } \\
\text { points of sales }\end{array}$ & $\begin{array}{c}3,58 \\
(2,23)\end{array}$ & $\begin{array}{c}2,75 \\
(1,66)\end{array}$ & $\begin{array}{c}2,00 \\
(1,73)\end{array}$ & $\begin{array}{c}2,27 \\
(1,36)\end{array}$ & $\begin{array}{c}3,45 \\
(2,06)\end{array}$ & $\begin{array}{c}2,19 \\
(1,02)\end{array}$ & 5,187 \\
\hline $\begin{array}{l}\text { Responsiveness in } \\
\text { delivering to the } \\
\text { arranged point of } \\
\text { sale }^{2}\end{array}$ & $\begin{array}{c}1,81 \\
(1,23)\end{array}$ & $\begin{array}{c}1,89 \\
(1,47) \\
\end{array}$ & $\begin{array}{c}1,23 \\
(0,44) \\
\end{array}$ & $\begin{array}{c}1,56 \\
(1,00) \\
\end{array}$ & $\begin{array}{c}2,20 \\
(1,69) \\
\end{array}$ & $\begin{array}{c}1,38 \\
(0,57) \\
\end{array}$ & 2,594 \\
\hline $\begin{array}{c}\text { Raw materials' } \\
\text { quality }\end{array}$ & - & $\begin{array}{c}1,53 \\
(0,72)\end{array}$ & $\begin{array}{c}1,08 \\
(0,28)\end{array}$ & - & - & - & 4,961 \\
\hline $\begin{array}{c}\text { Product } \\
\text { conservation time }\end{array}$ & $\begin{array}{c}4,00 \\
(2,33)\end{array}$ & $\begin{array}{c}2,50 \\
(1,68)\end{array}$ & $\begin{array}{c}3,77 \\
(2,24)\end{array}$ & $\begin{array}{c}2,93 \\
(1,76)\end{array}$ & $\begin{array}{c}3,37 \\
(1,94)\end{array}$ & $\begin{array}{c}4,78 \\
(1,83)\end{array}$ & 6,579 \\
\hline $\begin{array}{l}\text { Quality of my } \\
\text { firm's products } \\
\text { packaging }^{2}\end{array}$ & $\begin{array}{c}2,50 \\
(1,84)\end{array}$ & $\begin{array}{c}1,80 \\
(1,01)\end{array}$ & $\begin{array}{c}1,62 \\
(1,66)\end{array}$ & $\begin{array}{c}2,35 \\
(1,93)\end{array}$ & $\begin{array}{c}3,17 \\
(2,32)\end{array}$ & $\begin{array}{c}2,84 \\
(2,27)\end{array}$ & 3,823 \\
\hline $\begin{array}{c}\text { Total evaluation of } \\
\text { firm's } \\
\text { sustainability } \\
\text { performance }^{2}\end{array}$ & $\begin{array}{c}2,46 \\
(1,42)\end{array}$ & $\begin{array}{c}2,23 \\
(0,97)\end{array}$ & $\begin{array}{c}1,46 \\
(0,52)\end{array}$ & $\begin{array}{c}2,09 \\
(0,85)\end{array}$ & $\begin{array}{c}2,23 \\
(0,97)\end{array}$ & $\begin{array}{c}1,81 \\
(0,63)\end{array}$ & 2,816 \\
\hline
\end{tabular}

Notes: 1:percentage of turnover, 2:Seven point Likert scale (lower values indicate better sustainable performance), 3: the question concerns only small dairy manufacturers and large dairy manufacturers, $4: p<0,05$ 
Table 4: Significant differences between the dairy chain members' sustainability performance and the average chain sustainability performance

\begin{tabular}{|c|c|c|c|c|c|c|c|}
\hline $\begin{array}{c}\text { Sustainability } \\
\text { Performance } \\
\text { indicator* }\end{array}$ & \begin{tabular}{|c|} 
\\
Breeders \\
Mean \\
$(\mathrm{N}=26)$ \\
$(T-$ test $)$ \\
\end{tabular} & \begin{tabular}{|} 
Small dairy \\
manu- \\
facturers \\
Mean \\
$(\mathrm{N}=67)$ \\
$(T-t e s t)$ \\
\end{tabular} & $\begin{array}{l}\text { Large dairy } \\
\text { manu- } \\
\text { facturers } \\
\text { Mean } \\
(\mathrm{N}=11) \\
(T-t e s t)\end{array}$ & $\begin{array}{l}\text { Whole- } \\
\text { salers } \\
\text { Mean } \\
(\mathrm{N}=70) \\
(T \text {-test })\end{array}$ & $\begin{array}{c}\text { Retai- } \\
\text { lers } \\
\text { Mean } \\
(\mathrm{N}=53) \\
(T \text {-test }) \\
\end{array}$ & $\begin{array}{l}\text { Catering } \\
\text { firms } \\
\text { Mean } \\
(\mathrm{N}=26) \\
(T-t e s t)\end{array}$ & $\begin{array}{c}\text { Dairy } \\
\text { chain } \\
\text { Mean } \\
(\mathrm{N}=253) \\
(T-t e s t)\end{array}$ \\
\hline $\begin{array}{c}\text { Producing/ } \\
\text { operational/ raw } \\
\text { material cost } \\
\end{array}$ & & $\begin{array}{c}60,62 \\
(3,033) \\
\end{array}$ & & $\begin{array}{c}35,26 \\
(-2,378) \\
\end{array}$ & & $\begin{array}{c}32,07 \\
(-4,405) \\
\end{array}$ & 49,33 \\
\hline Gross profit margin & & & & $\begin{array}{c}7,76 \\
(-3,070)\end{array}$ & & & 11,84 \\
\hline Storage cost ${ }^{1}$ & & & & & $\begin{array}{c}2,91 \\
(-3,653 \\
\end{array}$ & & 5,68 \\
\hline $\begin{array}{c}\text { Delivery and } \\
\text { distribution cost }\end{array}$ & $\begin{array}{c}3,31 \\
(-2,187)\end{array}$ & & & & $\begin{array}{c}2,91 \\
(-5,321 \\
\end{array}$ & & 6,12 \\
\hline Waste & & & & & $\begin{array}{c}2,76 \\
(-2,521\end{array}$ & & 3,89 \\
\hline Financial cost & & & & $\begin{array}{c}6,25 \\
(-2,476)\end{array}$ & & & 9,64 \\
\hline $\begin{array}{l}\text { Flexibility in extra } \\
\text { volume orders }\end{array}$ & & & & & & $\begin{array}{c}2,04 \\
(-2,069) \\
\end{array}$ & 2,49 \\
\hline $\begin{array}{c}\text { Flexibility in } \\
\text { delivering to extra } \\
\text { points of sales }\end{array}$ & & & & $\begin{array}{c}2,27 \\
(-2,942) \\
\end{array}$ & $\begin{array}{c}3,45 \\
(2,481) \\
\end{array}$ & $\begin{array}{c}2,19 \\
(-2,786) \\
\end{array}$ & 2,75 \\
\hline $\begin{array}{c}\text { Responsiveness in } \\
\text { the arranged lead } \\
\text { time }\end{array}$ & & & & & & $\begin{array}{c}1,35 \\
(-2,773) \\
\end{array}$ & 1,61 \\
\hline $\begin{array}{c}\text { Responsiveness in } \\
\text { delivering to the } \\
\text { arranged point of sale }\end{array}$ & & & $\begin{array}{c}1,23 \\
(-4,351)\end{array}$ & & & $\begin{array}{c}1,38 \\
(-2,102)\end{array}$ & 1,76 \\
\hline \begin{tabular}{|} 
Responsiveness in \\
delivering the \\
ordered type of \\
product (exact code, \\
quality, etc) \\
\end{tabular} & & & $\begin{array}{c}1,23 \\
(-3,200) \\
\end{array}$ & & & & 1,62 \\
\hline $\begin{array}{c}\text { Raw materials' } \\
\text { quality }\end{array}$ & & & $\begin{array}{c}1,08 \\
(-4,850) \\
\end{array}$ & & & & 1,45 \\
\hline $\begin{array}{c}\text { Product } \\
\text { conservation time }\end{array}$ & & $\begin{array}{c}2,50 \\
(-3,522) \\
\end{array}$ & & & & $\begin{array}{c}4,78 \\
(4,036) \\
\end{array}$ & 3,24 \\
\hline $\begin{array}{c}\text { Show consistency in } \\
\text { following a } \\
\text { traceability system }\end{array}$ & & & $\begin{array}{c}1,08 \\
(-11,610)\end{array}$ & & & & 1,97 \\
\hline $\begin{array}{c}\text { Storage and delivery } \\
\text { conditions }\end{array}$ & & & $\begin{array}{c}1,15 \\
(-3,095)\end{array}$ & & & & 1,63 \\
\hline $\begin{array}{l}\text { Quality of my firm's } \\
\text { products packaging }\end{array}$ & & $\begin{array}{c}1,80 \\
(-4,695) \\
\end{array}$ & & & $\begin{array}{c}3,17 \\
(2,321)\end{array}$ & & 2,39 \\
\hline
\end{tabular}




\begin{tabular}{|c|l|c|l|l|l|l|}
\hline $\begin{array}{c}\text { Total evaluation of } \\
\text { firm's sustainability } \\
\text { performance }\end{array}$ & & $\begin{array}{c}1,46 \\
(-4,645)\end{array}$ & & & 1,81 & $(-2,594)$ \\
\hline $\begin{array}{c}\text { Total evaluation of } \\
\text { firm's sustainability } \\
\text { performance from } \\
\text { the market's point of } \\
\text { view }\end{array}$ & & & & & & \\
\hline
\end{tabular}

* No significant differences were identified between each single member's performance and the whole chain's performance in relation to the "quality of my firm's product" indicator (whole dairy chain's mean: 1,88 ; breeders' mean: $2,19(\mathrm{t}=0,639)$; small dairy manufacturers' mean: $1,58(\mathrm{t}=-1,894)$; large dairy manufacturers' mean: $1,83(\mathrm{t}=-0,087)$; wholesalers' mean: $2,00(\mathrm{t}=0,560)$; retailers' mean: $1,68(\mathrm{t}=-1,114)$; catering firms' mean: 2,36 ( $\mathrm{t}=1,002))$. Therefore, this indicator was not included in Table 4.

\section{APPENDIX}

\section{SUSTAINABILITY PERFORMANCE (DAIRY CHAIN QUESTIONNAIRE)}

\section{Sustainability Performance Indicators of Efficiency}

Please indicate the following costs and revenues of your firm as a \% of your firm's turnover.

\begin{tabular}{|l|c|}
\hline & $\begin{array}{c}\text { \%o of firm's } \\
\text { turnover }\end{array}$ \\
\hline $\begin{array}{l}\text { Producing / operational / raw material } \\
\text { cost }\end{array}$ & $\ldots$ \\
\hline Gross profit margin & $\ldots$ \\
\hline Storage cost & $\ldots$ \\
\hline Delivery and distribution cost & $\ldots$ \\
\hline Waste & $\ldots$ \\
\hline Financial costs (loans etc) & $\ldots$ \\
\hline
\end{tabular}

\section{Sustainability Performance Indicators of Flexibility}

Please indicate how your firm performs in the following sustainability performance indicators (1: very satisfactory sustainability performance - 7: very unsatisfactory sustainability performance).

\begin{tabular}{|l|c|c|c|c|c|c|c|}
\hline & $\begin{array}{c}\text { Very } \\
\text { satisfactory } \\
\text { sustainability } \\
\text { performance }\end{array}$ & & & & & & $\begin{array}{c}\text { Very } \\
\text { unsatisfactory } \\
\text { sustainability } \\
\text { performance }\end{array}$ \\
\hline $\begin{array}{l}\text { Flexibility in extra } \\
\text { volume orders }\end{array}$ & 1 & 2 & 3 & 4 & 5 & 6 & 7 \\
\hline $\begin{array}{l}\text { Flexibility in delivering } \\
\text { to extra points of sales }\end{array}$ & 1 & 2 & 3 & 4 & 5 & 6 & 7 \\
\hline
\end{tabular}


Sustainability Performance Indicators of Responsiveness

Please indicate how your firm performs in the following sustainability performance indicators (1: very satisfactory sustainability performance - 7: very unsatisfactory sustainability performance).

\begin{tabular}{|l|c|c|c|c|c|c|c|}
\hline & $\begin{array}{c}\text { Very } \\
\text { satisfactory } \\
\text { sustainability } \\
\text { performance }\end{array}$ & & & & & & $\begin{array}{c}\text { Very } \\
\text { unsatisfactory } \\
\text { sustainability } \\
\text { performance }\end{array}$ \\
\hline $\begin{array}{l}\text { Responsiveness in the } \\
\text { arranged lead time }\end{array}$ & 1 & 2 & 3 & 4 & 5 & 6 & 7 \\
\hline $\begin{array}{l}\text { Responsiveness in } \\
\text { delivering to the } \\
\text { arranged point of sale }\end{array}$ & 1 & 2 & 3 & 4 & 5 & 6 & 7 \\
\hline $\begin{array}{l}\text { Responsiveness in } \\
\text { delivering the ordered } \\
\text { type of product (exact } \\
\text { code, quality, etc) }\end{array}$ & 1 & 2 & 3 & 4 & 5 & 6 & 7 \\
\hline
\end{tabular}

Sustainability Performance Indicators of Product Quality

Please indicate how your firm performs in the following sustainability performance indicators (1: very satisfactory sustainability performance - 7: very unsatisfactory sustainability performance).

\begin{tabular}{|l|c|c|c|c|c|c|c|}
\hline & $\begin{array}{c}\text { Very } \\
\text { satisfactory } \\
\text { sustainability } \\
\text { performance }\end{array}$ & & & & & $\begin{array}{c}\text { Very } \\
\text { unsatisfactory } \\
\text { sustainability } \\
\text { performance }\end{array}$ \\
\hline $\begin{array}{l}\text { Raw materials' } \\
\text { quality }\end{array}$ & 1 & 2 & 3 & 4 & 5 & 6 & 7 \\
\hline $\begin{array}{l}\text { Quality of my firm's } \\
\text { product }\end{array}$ & 1 & 2 & 3 & 4 & 5 & 6 & 7 \\
\hline $\begin{array}{l}\text { Product conservation } \\
\text { time }\end{array}$ & 1 & 2 & 3 & 4 & 5 & 6 & 7 \\
\hline $\begin{array}{l}\text { Show consistency in } \\
\text { following a traceability } \\
\text { system }\end{array}$ & 1 & 2 & 3 & 4 & 5 & 6 & 7 \\
\hline $\begin{array}{l}\text { Storage and delivery } \\
\text { conditions }\end{array}$ & 1 & 2 & 3 & 4 & 5 & 6 & 7 \\
\hline $\begin{array}{l}\text { Quality of my firm's } \\
\text { products packaging }\end{array}$ & 1 & 2 & 3 & 4 & 5 & 6 & 7 \\
\hline *: The question was given to only small and large dairy manufacturers & \\
\hline
\end{tabular}


Total Evaluation of Sustainability Performance Indicators

Please indicate how your firm performs in the following sustainability performance indicators (1: very satisfactory performance and 7: very unsatisfactory performance).

\begin{tabular}{|l|c|c|c|c|c|c|c|}
\hline & $\begin{array}{c}\text { Very } \\
\text { satisfactory } \\
\text { sustainability } \\
\text { performance }\end{array}$ & & & & & & $\begin{array}{c}\text { Very } \\
\text { unsatisfactory } \\
\text { sustainability } \\
\text { performance }\end{array}$ \\
\hline $\begin{array}{l}\text { Total evaluation of } \\
\text { firm's sustainability } \\
\text { performance }\end{array}$ & 1 & 2 & 3 & 4 & 5 & 6 & 7 \\
\hline $\begin{array}{l}\text { Total evaluation of } \\
\text { firm's sustainability } \\
\text { performance from the } \\
\text { market's point of view }\end{array}$ & 1 & 2 & 3 & 4 & 5 & 6 & 7 \\
\hline
\end{tabular}

\section{Demographics}

Please indicate which of the following describes better the position of your firm in the dairy supply chain.

\begin{tabular}{|l|c|}
\hline Breeders & $\square$ \\
\hline $\begin{array}{l}\text { Small dairy } \\
\text { manufacturers }\end{array}$ & $\square$ \\
\hline $\begin{array}{l}\text { Large dairy } \\
\text { manufacturers }\end{array}$ & $\square$ \\
\hline Wholesalers & $\square$ \\
\hline Retailers & $\square$ \\
\hline Catering firms & $\square$ \\
\hline
\end{tabular}

Please indicate your firm's ...

\begin{tabular}{|c|c|}
\hline Annual turnover & \\
\hline Number of employees & \\
\hline Size of warehouses (in $\mathbf{~ m}^{2}$ ) & $\ldots \ldots \ldots \ldots \ldots \ldots \ldots+\ldots \ldots \ldots \ldots$ \\
\hline Number of Trucks & 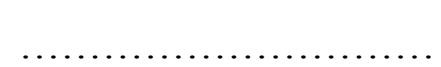 \\
\hline
\end{tabular}

